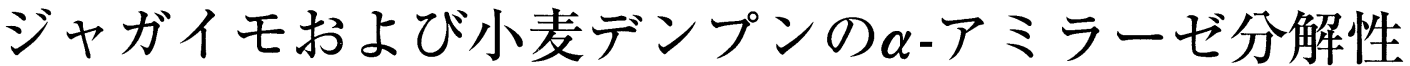 に及ぼす高圧処理の影響
}

\author{
野口智弘 ${ }^{* 1} \cdot$ 谷口（山田）亜樹子*2 $・$ 佐 藤広 顕*3 \\ 鈴木敏 郎 ${ }^{* 1} \cdot$ 松本信二*1 $\cdot$ 高野克已*3
}

\section{Effect of high-pressure treatment on decomposition of potato and wheat starch by $\alpha$-amylase}

\author{
Noguchi Tomohiro*1, Taniguchi (Yamada) Akiko*2, Sato Hiroaki*3 \\ Suzuki Toshiro*1, Matsumoto Shinji*1 and TAKano Katsumi*3 \\ * 1 Food Processing Center, Faculty of Applied Bioscience, Tokyo University of Agriculture \\ 1-1-1, Sakuragaoka,Setagaya-ku,Tokyo 156-8502 \\ * 2 Department of Brewing and Fermentation, Junior College of Tokyo University of Agriculture \\ 1-1-1, Sakuragaoka,Setagaya-ku,Tokyo 156-8502
}

* 3 Department of Applied Biology and Chemistry, Faculty of Applied Bioscience, Tokyo University of Agriculture 1-1-1, Sakuragaoka,Setagaya-ku,Tokyo 156-8502

Gelatinization of starch is essential in order to saccharify starch by amylase. Starch is gelatinized by heat-treatment, which requires a lot of energy. This study investigated the possibility of gelatinization of starch by high-pressure treatment, which was to make a better alternative to heat-treatment with respect to energy conservation. Potato and wheat starches were used in this study. Decomposition of potato starch by amylase accelerated after pressure treatment over $600 \mathrm{MPa}$, while that of wheat starch accelerated over $400 \mathrm{MPa}$. The transition enthalpy decreased at the pressure intensity, where the decomposition of starch accelerated by amylase. Although, the polarized light of small starch grains remained, the polarized light of large grains disappeared after high-pressure treatment. The result shows that the crystal structure of small grains in starch is much stronger than that of large grains. These results clearly show that the decomposition of starch by amylase accelerate after highpressure treatment because of the crystallinity of starch changed by high-pressure treatment.

(Received Jun. 2, 2003 ; Accepted Oct. 10, 2003)

デンプンは，液糖の製造やアルコール発酵などの原料， ならびに増粘剤, 糊料などとして重要な役割を担ってい る。液糖およびアルコールなどの製造においては，デン プンのアミラーゼによる分解が必要であり，このため， 耐熱性アミラーゼをはじめ, 様々なアミラーゼの研究開 発が行われてきた ${ }^{1), 2)}$ 。デンプンは結晶性粒子でアミラ 一ゼによる分解を効率よく行うために, 熱糊化が行われ る。このため省エネルギーの観点から, 生デンプン消化 性アミラーゼの開発も行われているが, 実用には至って いな( ${ }^{3), 4)}$ 。熱処理によらずデンプンを糊化させ，さら
にその老化防止が可能であれば，デンプンのアミラーゼ による分解に対する省エネルギー化，すなわち糖化工業 における $\mathrm{CO}_{2}$ 排出の削減に大きく貢献するものと考えら れる。

そこで, 本研究では生デンプンの新規糊化技術の開発 を目的とし, 従来行われている熱処理に比べ, より省工 ネルギー的な処理である超高圧処理によりデンプンの結 晶構造や表面構造を変化させ，アミラーゼによる分解性 とデンプンの結晶性や表面構造と関係について検討を行 った。

* 1 東京農業大学応用生物科学部食品加工技術センター（†156-8502 東京都世田谷区桜丘 1-1-1） E-mail : 野口智弘 ; tomo@nodai.ac.jp, 鈴木敏郎 ; tosuzuki@nodai.ac.jp, 松本信二 ; smatsu@nodai.ac.jp

*2 東京農業大学短期大学部酻造学科（T156-8502 東京都世田谷区桜丘 1-1-1） E-mail : akiko@nodai.ac.jp

*3 東京農業大学応用生物科学部生物応用化学科（†156-8502 東京都世田谷区桜丘 1-1-1） E-mail：佐藤広顕； hsato@nodai.ac.jp, 高野克已 ; takano@nodai.ac.jp 


\section{実験方法}

\section{1. 試料}

試料には，ジャガイモデンプン（ナカライテスク社 製）および小麦デンプン（和光純薬社製）を用いた。

\section{2. 高圧処 理}

$5 \%(\mathrm{~W} / \mathrm{V})$ 濃度となるようにデンプンを純水に懸 濁させ，ポリエチレン製の袋に密封後，超高圧処理装置 ITP-70（石川島播磨重工業社製）を用い，静水圧にて $10^{\circ} \mathrm{C} ， 30$ 分間行った。

3. $\alpha$-アミラーゼによるデンプン分解

（1） $\alpha$-アミラーゼによる分解試験 デンプン懸濁液 に，20mMトリス・塩酸緩衝液（pH 7.0） 1.5ml, 純水 $1.5 \mathrm{~m} \ell$ よび $\alpha$-アミラーゼ (Bachillus起源, シグマ社 製） 26.8 unitを加え， $37^{\circ} \mathrm{C} に て 3$ 時間振とう反応を行っ た。遠心分離後 $(3,000 \mathrm{rpm}, 10$ 分)，上澄液中の全糖 量をフェノール・硫酸法 ${ }^{5), 6)}$ にて測定し，分解率を算出 した。

（2）分解生成物の分析上述の分解上澄液を減圧乾 固し，超純水にて再溶解後， $0.45 \mu \mathrm{m}$ のメンブランフィ ルターでろ過し, HPLC (Shodex DS - 4, 検出機 : 示 差屈折計・Shodex RI-71, カラム : Shodex SUGAR $\mathrm{SC} 1011 \times 2$, 溶離液: $\mathrm{H}_{2} \mathrm{O}$, 温度: $80^{\circ} \mathrm{C}$, 流速: $1.0 \mathrm{~m} \ell$,

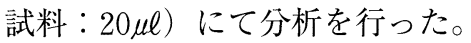

（3）基質親和性および最大反応速度デンプンに対

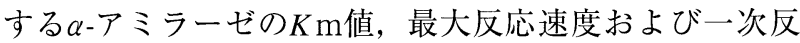
応速度定数は, Line-weaver-Burk ${ }^{7)}$ のプロットに従い算 出した。

\section{4. デンプンの構造解析}

\section{（1）示唆走査熱量測定（DSC） デンプン $2 \mathrm{m \ell}$} $(50 \mathrm{mg} / \mathrm{m} \ell)$ に, 純水を $1 \mathrm{~m} \ell$ 加え遠心分離 $(3,000 \mathrm{rpm}, 10$ 分）し，得られた沈殿 $5 \mathrm{mg}$ に純水 $10 \mu \ell を$ 加え，アルミ製 シールセルに密封後，示差走査熱量計（島津社製，DSC -60）にて昇温速度 $1{ }^{\circ} \mathrm{C} /$ 分で測定を行った。対照とし

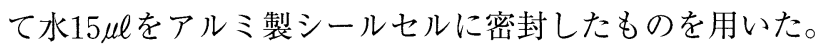

（2）偏光顕微鏡観察 デンプンをスライドガラス上

にスポットし，偏光顕微鏡（オリンパス社製， model POS）を用い，200倍にて行った。

（３）酸分解試験 デンプンの酸分解試験は, Nägeli の方法に従い行った ${ }^{8), 9)}$ 。デンプン眯濁液 $2 \mathrm{~m} \ell$ （50mg/ $\mathrm{m} \ell$ ）を遠心分離（3,000 rpm, 10分）し，得られた沈殿 に $16 \%$ 硫酸溶液を $3 \mathrm{~m} \ell$ 加え，室温にて $0 \sim 9$ 日間処理し， 遠心分離 $(3,000 \mathrm{rpm}, 10$ 分）を行い, 上澄液中の全糖 量を測定し，分解率を求めた。

\section{結果および考察}

\section{1. デンプンの $\alpha$-アミラーゼ分解に及ぼす高圧処理の影} 響

Fig.1に，ジャガイモおよび小麦デンプンの $\alpha$-アミラ 一ゼ分解性に及ぼす高圧処理の影響を示した。ジャガイ モデンプンは，500 MPa（30分）以下の処理まででは, $\alpha$-アミラーゼの作用によるデンプンの分解率は，0.1〜 $0.2 \%$ あ゙あり，500MPa以下の高圧処理では $\alpha$-アミラーゼ による分解率は増加しなかった。600MPa処理では分解 率が15\%，さらに650MPa処理の場合には，デンプン分 解率は約 $52 \%$ と大きく増大した。

一方，小麦デンプンは $0 \sim 200 \mathrm{MPa}$ 処理（30分）では, 分解率は，6〜8\%でジャガイモデンプンに比べ大きな 值を示した。さらに，300MPa処理で約 $15 \% ， 400 \mathrm{MPa}$ で約70\%と分解率は大幅に増大し，600〜 650MPa処理 した場合には $\alpha$-アミラーゼによる分解率は約 $80 \%$ と大き く増大した。

Table 1 に650MPaにて高圧処理したデンプンの $\alpha$-アミ ラーゼによる分解生成物のHPLC分析結果を示した。ジ ヤガイモ，小麦両デンプンともにG 1 ～G 6 および 7 以上のオリゴ糖が確認され，特にG $5, \mathrm{G} 6$ の生成量が 最も多く，次いでG 7 以上, G $3, \mathrm{G} 2, \mathrm{G} 4$ および $\mathrm{G} 1$ であった。G1の生成量を 1 とすると, 各糖 $(\mathrm{G} 1$ ：G $2: \mathrm{G} 3: \mathrm{G} 4: \mathrm{G} 5,6: \geqq \mathrm{G} 7$ ）の生成比はジャガイ モデンプンでは $1 ： 5: 6: 2 ： 24: 17$, 小麦デンプン では $1 ： 4 ： 6 ： 2 ： 24 ： 16$ と両デンプン間に分解パ夕

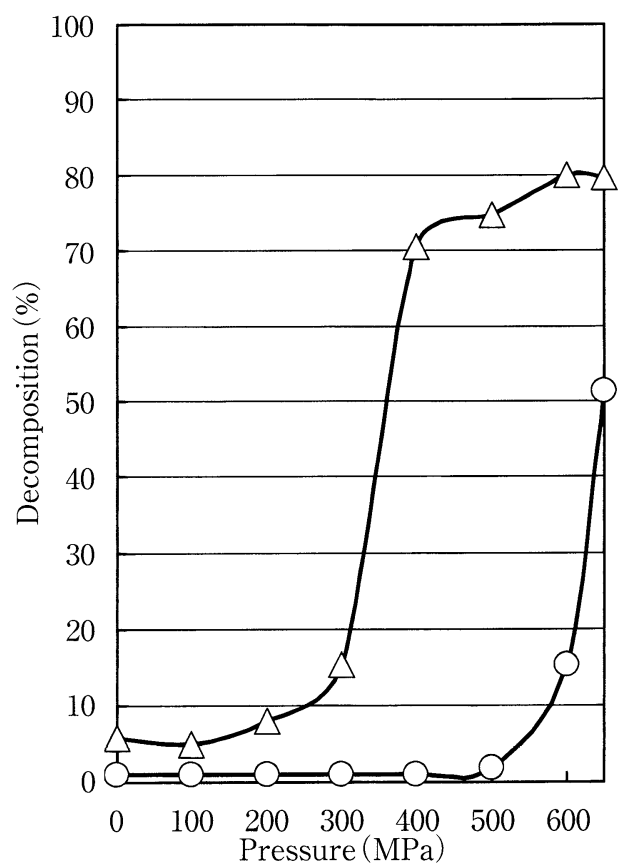

Fig. 1 Decomposition of high-pressure treatment starch by $\alpha$-amylase 
Table 1 HPLC analysis of decomposition product of starch with $650 \mathrm{MPa}$ high-pressure treatment by $\alpha$ amylase

\begin{tabular}{|c|c|c|}
\hline \multirow{2}{*}{ Composition sugar } & \multicolumn{2}{|c|}{ Ratio } \\
\hline & Potato & Wheat \\
\hline G 1: Glucose & 1 & 1 \\
\hline G 2: Maltose & 5 & 4 \\
\hline G $3:$ Maltotriose & 6 & 6 \\
\hline G 4 : Maltotetraose & 2 & 2 \\
\hline G 5 : Maltopentaose & & \\
\hline G 6 : MaltoHexaose & 24 & 24 \\
\hline$\geqq \mathrm{G} \quad 7:$ Maltoheptaose & 17 & 16 \\
\hline
\end{tabular}

ーンに差異はみられなかった。

以上のように，高圧処理によってデンプンの $\alpha$-アミラ 一ゼによる分解性は，大きく増大した。しかし，その効 果はデンプンの種類によって差がみられた。ジャガイモ デンプンは生デンプンの状態では, 他起源のデンプンに 比ベアミラーゼによる分解性が低い。高圧処理の影響に も大きな差異がみられたことから，ジャガイモデンプン の結晶構造が他の起源のデンプンに比べ強固であること が推察された。

\section{2. デンプンの構造に与える高圧処理の影響}

（1）糊化吸熱量の挙動 高圧処理によるジャガイモ および小麦デンプンの糊化吸熱量の変化をFig. 2 に示し た。ジャガイモデンプンは，500MPa以下の処理では， 糊化吸熱量はいずれの圧力でも2.01〜2.23 J/g と大き な変化はみられなかった。 $600 \mathrm{MPa}$ 処理にて1.17J，650

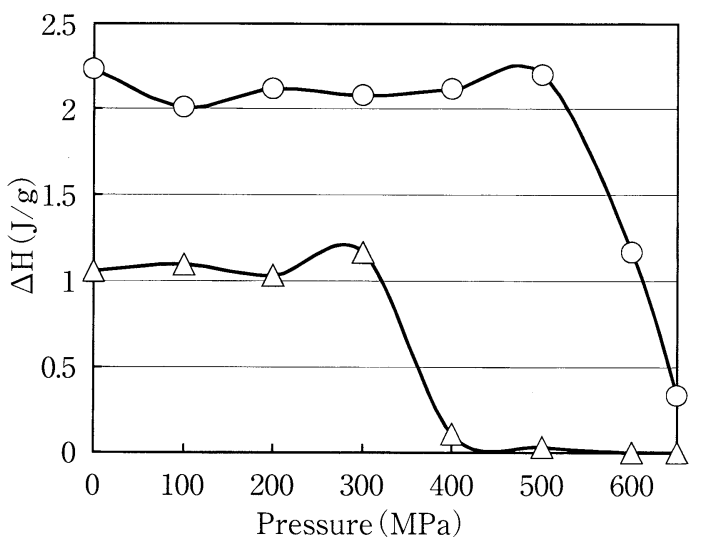

Fig. 2 Effect of high-pressure treatment on enthalpies of starch

$$
- \text {-Potato, } \triangle \text { Wheat }
$$

$\mathrm{MPa}$ 処理で0.33J と無加圧に比べ $1 / 7$ に低下した。小麦 デンプンでは，300MPa以下の処理では糊化吸熱量は $1.03 \sim 1.17 \mathrm{~J} / \mathrm{g}$ 大きな変化はみられず，400MPa以上で 大幅な吸熱量の低下が観察されたことから，高圧処理に より熱糊化と同様に結晶性が崩壊することが明らかにな つた。

また，これら糊化吸熱量の減少と, 先の $\alpha$-アミラーゼ による分解性増大に対する圧力の影響は両デンプンとも 一致した。このことから， $\alpha$-アミラーゼによる分解率の 増大は，デンプンの高圧処理による結晶性の低下による ものと推察した。

（2）偏光顕微鏡による観察 Fig. 3に高圧処理を行 ったデンプンの偏光顕微鏡による観察の結果を示した。

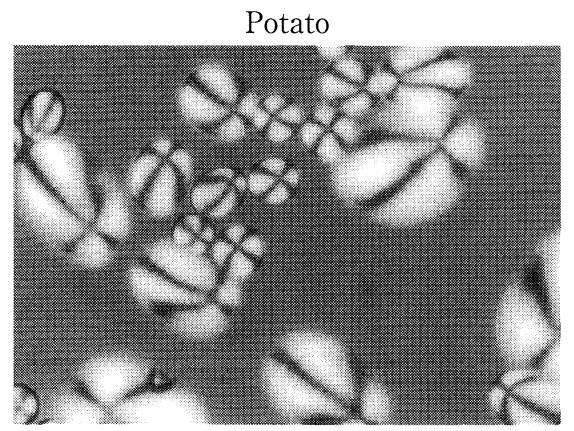

$0 \mathrm{MPa}$

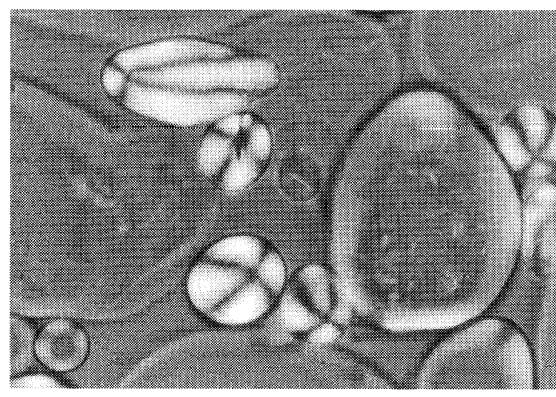

$650 \mathrm{MPa}$
Wheat

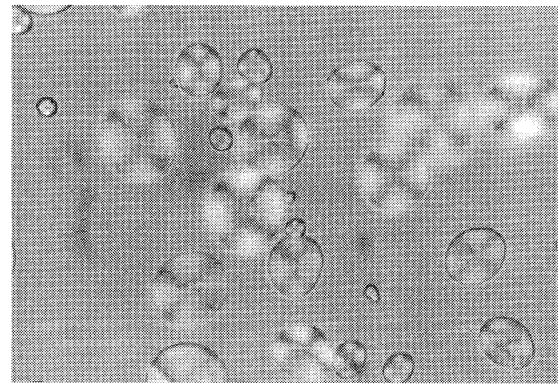

$0 \mathrm{MPa}$

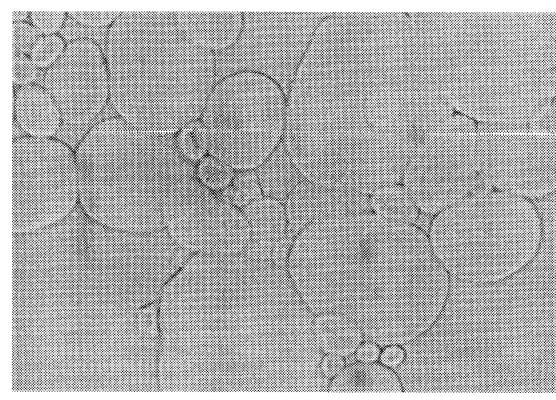

$650 \mathrm{MPa}$

Fig. 3 Photograph of polarization microscope of starch treated by high-pressure $(\times 200)$ 
ジャガイモ，小麦両デンプンともに無加圧では，すべて のデンプン粒子に偏光十字が観察された。一方, $650 \mathrm{MPa}$ 処理のジャガイモデンプンでは, 一部に偏光十字の消失 が観察され, また偏光十字の消失した粒子は, 粒子全体 が 2 〜 倍に膨潤していた。また, 小麦デンプンでは, 650 $\mathrm{MPa}$ 処理によりすべての粒子において偏光十字が消失 し膨潤していた。両デンプンともに650MPaの高圧処理 により結晶構造の一部またはすべてが崩壊することが明 らかになった。しかし，デンプン粒子が溶解するまでに は至らず，粒子の輪郭は保持していた。

なお， $650 \mathrm{MPa}$ の処理による両デンプンの偏光十字消 失の挙動に差異が生じたのは, 両デンプン粒の結晶構造 の違いが影響しているものと推察した。

また，650MPa処理のジャガイモデンプンで，一部の 粒子に偏光十字が観察され, これらは, 偏光十字が消失 した粒子よりもいずれも粒子が小さかった。このことか ら, ジャガイモデンプンの小粒子は, 大粒子に比べ結晶 構造が強固であることが推察された。

（３）酸分解試験両デンプンの結晶性および高圧処 理の影響を調べるため, 酸分解試験を行った。Fig.4に 示したように，無加圧のジャガイモおよび小麦デンプン は, 酸処理による分解率が日数に従い比例して増加し 9 日目ではそれぞれ約 $8 \%$ および約13\%を示し，ジャガイ モデンプンは，小麦デンプンに比べ結晶性が大きかった。 一方， 650MPa処理デンプンでは，9 日目において分解 率はジャガイモデンプンが約25\%，小麦デンプンが約 $50 \%$ あり，両デンプンとも未処理に比べ高い分解率を 示した。

生デンプンは，高い結晶性のため酸による分解を受け 難いが，650MPa処理によって，結晶性の指標である偏 光十字が消失したことから, 高圧処理によるデンプンの 酸分解率の増加は, その結晶構造の崩壊によることが明

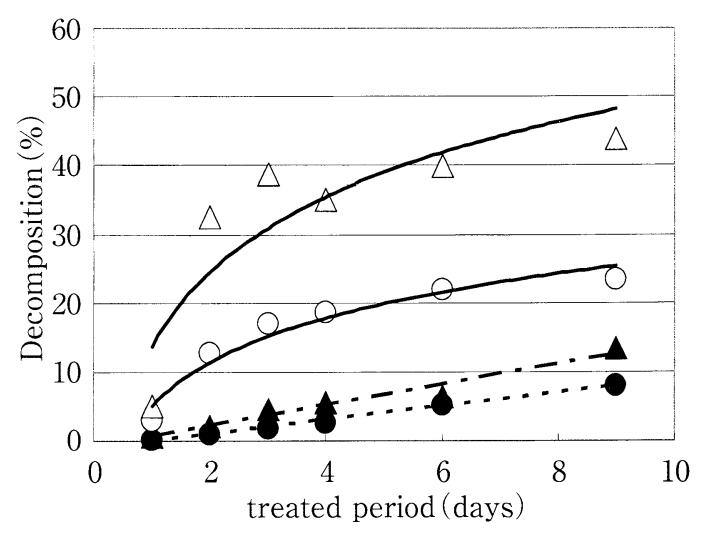

Fig. 4 Decomposition of $650 \mathrm{MPa}$ high-pressure treated starch with sulfuric acid

- Potato, non-Pressure, - - - Potato, $650 \mathrm{MPa}$

- Wheat, non-Pressure, $\triangle$-Wheat, $650 \mathrm{MPa}$
らかになった。

無加圧デンプンでは，いずれも酸による分解率が処理 日数に従いほぼ直線的に増加した。一方，650MPa処理 した両デンプンとも，それぞれ 2 日目で，9 日目の約 $50 \%$ の分解率に達し，それ以降の分解率の上昇は緩慢であっ た。このような分解率の挙動は, 高圧処理デンプンの結 晶構造の崩壊が粒内で均一に起こっているのではないこ とを示唆しているものと考えられた。また，小麦デンプ ンはジャガイモデンプンに比べ分解率およびその上昇が 大きかったが，これは両デンプンの結晶構造の強さを反 映したものと推察した。

\section{3 ．基質親和性および最大反応速度}

Table 2 に，ジャガイモデンプンに対する $\alpha$-アミラー ゼの $K \mathrm{~m}$ 值, 最大反応速度および一次反応速度定数を示 した。 $K \mathrm{~m}$ 值は無加圧, $600 \mathrm{MPa}$ 処理デンプンともに同 様の值を示し $\alpha$-アミラーゼのジャガイモデンプンに対す る基質親和性に対し，高圧処理はほとんど影響がみられ なかった。一方, 最大反応速度および一次反応速度定数 は，600MPa処理により無加圧の約13倍の值を示した。 これらのことより，高圧処理によるデンプンの $\alpha$-アミラ 一ゼ分解性は, 加水分解速度が速くなることによって, 大幅に増加することが明らかとなった。

Table 2 Effect of high-pressure treatment at $K \mathrm{~m}$, $V \max$ and $V \max / K \mathrm{~m}$ to potato starch of $\alpha$-amylase

\begin{tabular}{|c|c|c|c|c|c|}
\hline \multicolumn{2}{|c|}{$\begin{array}{c}K \mathrm{~m} \\
(\mathrm{mg} / \mathrm{m} \ell)\end{array}$} & \multicolumn{2}{|c|}{$\begin{array}{c}V \max \\
\left(10^{-4} \mathrm{mg} / \mathrm{m} \ell / \mathrm{min}\right)\end{array}$} & \multicolumn{2}{|c|}{$\begin{array}{l}V \max / K \mathrm{~m} \\
\left(10^{-5} / \mathrm{min}\right)\end{array}$} \\
\hline 0 & $600(\mathrm{MPa})$ & 0 & $600(\mathrm{MPa})$ & 0 & $600(\mathrm{MPa})$ \\
\hline 35.12 & 37.84 & 13.85 & 187.01 & 3.94 & 49.42 \\
\hline
\end{tabular}

要 約

各種デンプン中で最も難分解性であるジャガイモデン プンの $\alpha$-アミラーゼ分解性に及ぼす高圧処理の影響につ いて検討を行い，またジャガイモデンプンに比べ分解性 の高い小麦デンプンを比較対照として試験を行った。ジ ヤガイモデンプンでは，600MPa以上の処理によって分 解率の増大がみられたのに対し，小麦デンプンは400 $\mathrm{MPa}$ 以上の処理により分解性が著しく増加し, 両デン プンの耐圧性に大きな差異がみられ，ジャガイモデンプ ンは他起源のデンプンに比べ構造が強固であることが推 察された。また，両デンプンの $\alpha$-アミラーゼによる分解 生成物のパターンを測定したところ，ジャガイモ，小麦 両デンプンともにG 5 以上のオリゴ糖の生成が多く，両 デンプン間の分解パターンに差異はみられなかった。さ らに, $600 \mathrm{MPa}$ の高圧処理による分解性の増大は, $K \mathrm{~m}$ 值に変化はみられず, 最大反応速度が大きく増加したこ 
とより，加水分解速度が速くなることによって，大幅に 増加することが明らかとなった。

また, 糊化吸熱量はジャガイモデンプンで600MPa以 上，小麦デンプンでは400MPa以上の圧力処理にて著し く低下し，これら糊化吸熱量の減少は， $\alpha$-アミラーゼに よる分解性増大圧力量と一致した。

さらに, 高圧処理デンプンの構造は, 生デンプンの結 晶性構造の指標である偏光十字が, ジャガイモデンプン では, $650 \mathrm{MPa}$ 処理にて一部消失し, 小麦デンプンでは, すべてが消失した。これら，偏光十字が消失した粒子は， 粒子全体が膨潤していたが，熱糊化デンプンのようなデ ンプン粒子が溶解するまでには至らず，粒子の輪郭は保 持していた。また，偏光十字が観察された粒子は，消失 したデンプン粒より，いずれも粒子が小さかった。この ことから, ジャガイモデンプンの小粒子は, 大粒子に比 べ結晶構造が強固であることが推察された。また，酸に よる分解性は両デンプンともに650MPa処理で大きく増 大し, 酸処理初期に分解が進みが大きく, それ以降の分 解率の上昇は緩慢であった。このような分解率の挙動は, 高圧処理デンプンの結晶構造の崩壊が粒内で均一に起こ っているものではないことを示唆しているものと考えら れた。

以上のことから，デンプンは高圧処理によりその結晶 性が低下し, 酵素反応の反応速度が増加する構造へ変化 することで， $\alpha$-アミラーゼによる分解性が増大すること 明らかとなった。

\section{文献}

$1)$ Sasaki, H., Kurosawa, K. and TAKaO, S. : Screening of Microorganisms for Raw Starch Saccharifying Enzyme Production, Agric. Biol. Chem., 50, 1661 (1986)

2) Takao, S., Sasaki, H., Kurosawa, K., TAnida, M. and Kamagata, Y.: Production of Raw Starch Saccharifying Enzyme by Corticium rolfii, Agric. Biol. Chem., 50, 1978 (1986)

3 ）高崎義幸：耐酸・耐熱性 $\alpha$-アミラーゼの開発, 食品 工業，37，44（1994）

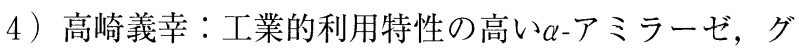
ルコースイソメラーゼ及びマンノースイソメラーゼの 探索とその性質，日食科工誌，48，150（2001）

5 ) Dubois, M., Gilles, K. A., Hamilton, J. K., Rebers, P. A. and Smith, F.: Anal. Chem., 28, 350 (1956)

6 ) Hodge, J. E. and Hofreiter, B. T.: Methods in Carbohydrate Chemistry (Academic Press, New York), 1, p.388 (1962)

7 ) 永井 裕・石倉久之・林 利彦：シーゲル・生化学 計算法（廣川書店，東京）pp. 263〜276（1985）

8 ）鈴木繁男 - 中村道徳：澱粉科学実験法（朝倉書店, 東京), pp. 183〜196（1979）

9 ）檜作 進・竹田靖史・今村茂行：甘藷でんぷん粒の 酸分解とNägeli型アミノデキストリンの迅速調製に関 する研究, 日農化誌, 46, 119 (1972)

(平成15年 6 月 2 日受付, 平成15年10月 10 日受理) 